\title{
Konflik Batin Tokoh Utama dalam Novel Pertanyaan Kepada Kenangan Karya Faisal Oddang (Tinjauan Psikologi Sastra)
}

\author{
Vivi Hikmawati ${ }^{1}$ \\ Suntoko² \\ Wienike Dinar Pratiwi ${ }^{3}$
}

\section{Pendidikan Bahasa dan Sastra Indonesia Fakultas Keguruan dan Ilmu Pendidikan Universitas Singaperbangsa Karawang}

11710631080163@student.unsika.ac.id

22suntoko@fkip.unsika.ac.id

33ienike.dinar@fkip.unsika.ac.id

\begin{abstract}
Abstrak
Tujuan yang ingin dicapai dalam penelitian ini adalah mendeskripsikan unsur intrinsik novel Pertanyaan Kepada Kenangan karya Faisal Oddang, dan mendeskripsikan konflik batin yang dialami tokoh utama dalam novel Pertanyaan Kepada Kenangan karya Faisal Oddang. Permasalahan yang terjadi yaitu konflik yang dialami pada tokoh Rinai dalam novel Pertanyaan Kepada Kenangan karya Faisal Oddang. Teori yang digunakan yaitu Psikologi Sastra menurut Sigmund Freud untuk menganalinis psikologi tokoh, dan teori konflik menurut Kurt Lewin untuk menganalisis konflik batin tokoh. Pendekatan penelitian yang digunakan adalah kualitatif sedangkan metode penelitian yang digunakan adalah metode deskriptif analisis. Sumber data dalam penelitian ini adalah buku novel Pertanyaan Kepada Kenangan karya Faisal Oddang. Hasil penelitian ini menggambarkan tokoh utama Rinai mengalami konflik batin, dilihat dari beberapa situasi yang mengekspesikan tokoh. Pertama, ketika Rinai diterima di majalah pariwisata internasional dan di tempatkan di Makassar, selain itu Rinai dicintai oleh dua pria sekaligus. Kedua, ketika Lamba mengajak Rinai untuk bertemu dengan alasan mamanya. Ketiga, ketika Rinai bertemu Lamba di Toraja, padahal niat Rinai ke Toraja untuk menenangkan diri dari perasaan gamang setelah Wanua menyatakan cintanya. Dari hasil penelitian bahwasannya konflik batin yang di alami tokoh Rinai cukup berat, Rinai dihadapkan pada beberapa pilihan yang harus dipilih dalam waktu bersamaan sehingga mengakibatkan konflik batin.
\end{abstract}

Kata kunci: Konflik Batin Tokoh, Novel, Psikologi Sastra

\section{Pendahuluan}

Karya sastra digunakan sebagai sarana untuk mengekspresikan jiwa pengarang yang dipengaruhi oleh kehidupannya, baik itu pengalaman pribadi maupun permasalahan kehidupan manusia. Pengarang lahir dari anggota masyarakat dan lingkungan selalu memengaruhi terciptanya sebuah karya sastra, oleh karena itu karya sastra terbentuk dari cerminan kehidupan masyarakat. Hal tersebut sesuai dengan pandangan Sapardi Djoko Damono yang menyatakan bahwa karya sastra tidak jatuh 
begitu saja dari langit, tetapi selalu ada hubungannya antara sastrawan, sastra, dan masyarakat (Wiyatmi, 2009: 97).

Bentuk karya sastra yaitu prosa (cerita pendek dan novel), puisi, drama (naskah drama atau pementasan drama). Novel termasuk ke dalam karya sastra berbentuk prosa. Novel sebagai salah satu jenis karya sastra ditulis oleh pengarang yang merupakan bagian dari masyarakat. Dalam novel mengungkapkan seluruh episode perjalanan hidup tokohtokoh yang diceritakannya (Sehandi, 2018: 54). Di dalam setiap novel mengandung sebuah rangkaian cerita kehidupan, sosial, dan budayanya seperti yang terdapat pada novel Siti Nurbaya karya Marah Rusli, Tenggelamnya Kapal Van der Wijck karya Hamka, Pertanyaan kepada Kenangan karya Faisal Oddang, dan masih banyak lagi.

Dalam penelitian ini menggunakan novel Pertanyaan Kepada Kenangan karya Faisal Oddang. Novel Pertanyaan Kepada Kenangan karya Faisal Oddang menceritakan tentang perjalanan hidup tokoh yang memiliki kebudayaan berbeda. Tokoh utama diperankan oleh Rinailah Rindu yang berkebudayaan Jawa, dan tokoh tambahan diperankan oleh Lamba Dondi yang berkebudayaan Toraja. Kedua tokoh tersebut merupakan seorang kekasih yang tidak bisa melanjutkan hubungannya ke jenjang serius dikarenakan Lamba sangat memegang teguh adat kebudayaannya. Lamba yang belum mengadakan upacara kematian atau rambu solo dalam adat Toraja untuk papanya, ia tidak bisa mengadakan upacara kesenangan (pernikahan) sebelum upacara kedukaan digelar.

Lamba tidak ingin disebut sebagai anak durhaka, upacara rambu solo sangat sakral bagi keluarganya. Butuh waktu bertahun-tahun untuk menyiapkan upacara ini dengan biaya yang tidak sedikit. Mustahil jika Lamba melanjutkan pernikahan sebelum melaksanakan kewajiban me-rambu solo papanya. Hal tersebut membuat Lamba memutuskan hubungan dengan Rinai. Rinai merasa culture shock, karena mengadakan rambu solo tidak semudah melakukan acara kematian yang lain. Rinai gagal untuk memenuhi keinginan Ibunya hanya dikarenakan sebuah adat.

Disaat kesedihan Rinai, datanglah Wanua yang merupakan sahabat Rinai sejak SMP, Wanua tiba-tiba menyatakan perasaannya kepada Rinai. Wanua memiliki perasaan kepada Rinai sejak Rinai masih berpacaran dengan Lamba. Ketika datang kesempatan, Wanua menyatakan perasaannya dan ia tidak mau kehilangan Rinai untuk ke dua kalinya. Setelah tiga tahun kemudian Lamba bertemu dengan Rinai dan ia mengajak Rinai kembali untuk berhubungan dengannya. Berbagai usaha telah Lamba lakukan agar bisa kembali dengan Rinai. Rinai sangat dilema harus memilih Lamba dari masa lalunya atau Wanua yang merupakan sahabat dari sejak SMP.

Kehidupan tokoh pada novel Pertanyaan Kepada Kenangan karya Faisal Oddang sangat menarik untuk diteliti lebih dalam. Konflik-konflik yang terjadi dalam cerita juga menggambarkan kehidupan sehari-hari terkait percintaan namun mereka harus berhenti akibat sebuah adat istiadat. Dari peristiwa tersebut sangat mempengaruhi psikologi para tokoh akibat keinginannya yang tidak bisa terpenuhi.

Novel Pertanyaan Kepada Kenangan karya Faisal Oddang, berlatar pada keindahan Provinsi Sulawesi Selatan lebih tepatnya Tana Toraja dan Makasar. Sesuai dengan latar belakang penulis, Faisal Oddang lahir di Wajo, Sulawesi Selatan pada tahun 1994. Maka dari itu, pengarang dapat memengaruhi suatu karya sastra yang dihasilkannya. Banyak penghargaan yang pernah diraihnya, salah satunya yaitu menjadi penulis cerpen terbaik Kompas 2014 dan 2018; Pemenang IV Sayembara Novel Dewan Kesenian Jakarta 2014; Asean Young Writers Award 2014; Tokoh Seni Tempo 2015; Robert Bosch Stiftung and Literary Colloquium Berlin 2018; Lowa International Writing Program USA 2018; dan Finalis Kusala Sastra Khatulistiwa 2018. 
Pada hakikatnya penelitian ini ditinjau melalui pendekatan psikologi sastra, peneliti dapat menganalisis bagaimana kejiwaan yang dialami tokoh utama dalam karya sastra. Hal itu disebabkan karena karya sastra diciptakan oleh pengarang sebagai hasil aktivitas pengarang lalu dikaitkan dengan gejala-gejala kejiwaan pengarang. Sejalan dengan pendapat Ratna (Ratna, 2015: 61), pendekatan psikologi pada dasarnya berhubungan dengan tiga gejala utama, yaitu: pengarang, karya sastra, dan pembaca, dengan pertimbangan bahwa pendekatan psikologis lebih banyak berhubungan dengan pengarang dan karya sastra.

Analisis dalam penelitian ini merupakan analisis terhadap unsur-unsur intrinsik sebagai unsur pembangun di dalam karya sastra. Penelitian ini juga menganalisis konflik batin yang terjadi dalam novel Pertanyaan Kepada Kenangan karya Faisal Oddang dengan tinjauan psikologi sastra. Pendekatan psikologi sastra yang difokuskan pada teori struktur kepribadian Sigmund Freud, pendekatan tersebut cocok untuk menganalisis konflik batin yang terjadi pada tokoh. Tidak hanya itu, penelitian ini juga menganalisis konflik menurut Kurt Lewin yang terdiri dari konflik mendekat-mendekat, konflik mendekat-menjauh, dan konflik menjauh-menjauh.

Peneliti menemukan beberapa penelitian yang relevan, di antaranya, yaitu: Pertama, Suherman (2017) menerbitkan penelitiannya yang berjudul Analisis Psikologis Tokoh Andre dalam Novel Ibuku Perempuan Berwajah Surga; Kajian Teori Kepribadian Sigmund Freud. Dalam penelitian ini menjelaskan struktur kepribadian tokoh Andre dalam novel Ibuku Perempuan Berwajar Surga, dan terdapat enam belas aspek struktur kepribadian menurut Sigmund Freud. Diantaranya terdapat dua Id, tiga Ego, dan dua Super Ego yang dialami tokoh Andre untuk menikah dengan Risma. Selain itu, terdapat tiga Id, tiga Ego, dan tiga Super Ego tokoh Andre untuk bertemu dengan Risma (Suherman, 2017: 51).

Kedua, Wulandari (2018) menerbitkan penelitiannya yang berjudul Analisis Konflik Batin Tokoh Utama Tegar dalam Novel Sunset dan Rosie karya Tere Liye (Pendekatan Psikologi Sastra). Dalam penelitian ini menjelaskan lima teori kebutuhan untuk menganalisis konflik batin yang dialami tokoh utama Tegar. Lima teori kebutuhan yang digunakan dalam penelitian ini menurut Abraham Maslow, yaitu kebutuhan fisiologis, kebutuhan akan keamanan, kebutuhan akan cinta dan keberadaan, kebutuhan akan penghargaan, dan kebutuhan akan aktualisasi diri (Wulandari, 2018: 61).

Penelitian sejenis terkait konflik batin tokoh dalam novel telah banyak dilakukan, namun terdapat perbedaan dalam penelitian terdahulu. Perbedaan penelitian ini dengan penelitian terdahulu tentunya akan berbeda, mulai dari teori yang digunakan, ataupun sumber data yang digunakan. Dengan adanya penelitian ini diharapkan dapat menjadi bentuk apresiasi karya sastra bagi penikmat karya sastra. Alasan peneliti mengkaji novel Pertanyaan Kepada Kenangan karya Faisal Oddang, karena dalam novel ini karya yang dihasilkan oleh Faisal Oddang walaupun bergenre roman tapi Faisal selalu membumbui dengan unsur kebudayaan Indonesia terutama tentang tradisi dan adat istiadat di Sulawesi. Kelebihan dalam novel ini menceritakan konflik batin tokoh terkait percintaan yang harus berhenti karena terhalang ada. Novel ini bukanlah pemberontakan adat, melainkan konflik batin yang dialami tokoh terjadi karena ada budaya yang tidak memperbolehkan upacara kesenangan digelar sebelum upacara kedukaan digelar.

Rumusan masalah dalam penelitian ini dirumuskan sebagai berikut: Bagaimana unsur intrinsik novel Pertanyaan Kepada Kenangan karya Faisal Oddang? Dan Bagaimana konflik batin yang dialami tokoh utama dalam novel Pertanyaan Kepada Kenangan karya Faisal Oddang melalui pendekatan psikologi sastra? 


\section{Kerangka Teori}

\section{Hakikat Novel}

Karya sastra dapat diartikan sebagai hasil ekspresi pengalaman mistis dan estetis manusia melalui media bahasa sebagai hasil kreativitasnya yang bersifat imajinatif (Sehandi, 2018: 46). Karya sastra merupakan sebuah cerminan masyarakat, salah satu bentuk karya sastra yaitu novel. Menurut Clara Reeve (Wellek, Rene \& Warren, 2016: 260), novel adalah suatu ceriminan dari kehidupan dan perilaku yang nyata pada saat novel tersebut ditulis. Jadi, novel itu diciptakan oleh pengarang berdasarkan kehidupan yang realistis sesuai dengan kapan karya itu diterbitkan.

Menurut istilah, novel adalah suatu narasi yang panjang dan sering mengangkat kisah kehidupan manusia yang dibangun dari unsur intrinsik dan ekstrin sik. Sedangkan secara etimologi, novel berasal dari bahasa Latin yaitu novellus, kata tersebut diuturunkan dari kata noveles yang berarti baru. Novel muncul setelah puisi dan drama, maka dari itu novel dikatakan baru. Menurut pandangan Abrams (Nurgiyantoro, 2015: 11-12), mengungkapkan bahwa secara harfiah novella memiliki arti sebagai sebuah barang baru yang kecil, dan kemudian diartikan sebagai cerita pendek dalam bentuk prosa.

Secara umum novel dibangun oleh dua unsur pembangun, yaitu unsur intrinsik dan unsur ekstrinsik. Unsur intrinsik (intrinsic) adalah unsur pembangun di dalam karya sastra itu sendiri. Kedua unsur tersebut dapat menyebabkan suatu teks hadir sebagai pembangun teks sastra, dan unsur-unsur tersebut secara faktual dapat dijumpai ketika seseorang membaca sebuah karya sastra (Nurgiyantoro, 2015: 30). Unsur intrinsik merupakan pembangun cerita dalam novel, jika kita menjadi pembaca maka unsur intrinsik yang akan kita jumpai dalam sebuah novel. Menurut Burhan Nurgiyantoro (Darmawati, 2018: 17), unsur-unsur intrinsik karya sastra terdiri atas tema, perwatakan, alur atau plot, latar, pusat pengisahan, dan amanat. Dalam penelitian ini, hanya menganalisis unsur intrinsik sebagai unsur pembangun karya sastra.

\section{PSIKOLOGI SASTRA}

Psikologi sastra merupakan gabungan disiplin ilmu antara sastra dan psikologi. Ketika berbicara mengenai penelitian psikologi sastra, artinya peneliti melihat hubungan antara karya sastra dengan kejiwaan. Secara definitif, psikologi sastra adalah analisis terkait karya sastra untuk mempertimbangkan relevansi terhadap aspek-aspek psikologis atau kejiwaan yang terkandung di dalamnya. Pendekatan psikologi sastra banyak dikaitkan dengan tokoh dan penokohan, dengan tiga wilayah yang dapat dianalisis, yaitu psikologi pengarang, psikologi tokoh-tokoh dalam karya sastra, dan psikologi pembaca sastra (Sehandi, 2018: 42).

Dalam penelitian psikologi sastra dapat dilakukan melalui dua cara, pertama, melalui pemahaman teori-teori psikologi kemudian diadakan analisis terhadap suatu karya sastra. Kedua, dengan terlebih dahulu menentukan sebuah karya sastra sebagai objek penelitian, kemudian ditentukan teori-teori psikologi yang dianggap relevan untuk melakukan analisis (Ratna, 2015: 344).

Tokoh kunci teori psikologi sastra yang paling dominan dalam analisis karya sastra adalah Sigmund Freud (1856-1939). Sigmund Freud menjelaskan bahwa manusia 
lebih banyak dikondisikan oleh alam bawah sadar yang sering disebutnya sebagai "metafora gunung es". Wilayah alam bawah sadar ini tidak disadari oleh manusia, tetapi menentukan hampir keseluruhan kehidupannya. Freud membagi struktur kepribadian manusia menjadi tiga macam, yakni (1) id, (2) ego, (3) superego (Sehandi, 2018: 113).

Freud membagi struktur kepribadian manusia ke dalam tiga kategori yang saling berkaitan, yaitu Id, Ego, dan Superego. Berikut ini uraian kategori tersebut:

\section{a) Id}

Id merupakan struktur yang paling mendasar dari kepribadian yang dimiliki manusia, seluruhnya tidak disadari dan bekerja berdasarkan prinsip kesenangan, Id memiliki tujuan untuk memenuhi kepuasan yang segera (Sehandi, 2018: 113). Id terletak dibagian tak sadar yang merupakan reservoir pulsi dan menjadi sumber energi psikis (Minderop, 2011: 21).

\section{b) $\boldsymbol{E g o}$}

Ego merupakan perkembangan dari Id, struktur kepribadian ego bertugas untuk mengontrol kesadaran dan mengambil keputusan atas perilaku tindakan manusia (Sehandi, 2018: 113). Ego terletak diantara alam sadar dan alam bawah sadar yang kemudian bertindak sebagai penengah untuk mendamaikan tuntutan pulsi dan larangan superego (Minderop, 2011: 21).

\section{c) Superego}

Superego merupakan perkembangan dari ego saat manusia mengerti nilai baik dan nilai buruk serta nilai moral. Superego dapat merefleksikan nilai-nilai sosial dan menyadarkan individu atas tuntutan moral yang terjadi. Apabila terjadi pelanggaran, superego akan menghukum ego dengan memunculkan rasa bersalah. Ego selalu menghadapi ketegangan antara tuntuttan dari Id dan Superego. Apabila tuntutan yang dilakukan tidak berhasil diatasi dengan baik, maka ego dapat terancam dan akan muncul kecemasan (anxiety). Dalam rangka menyelematkan diri dari ancaman, ego akan melakukan reaksi definitif atau pertahanan diri (Sehandi, 2018: 113).

\section{Konflik Batin}

Menurut Agus Sujanto, konflik batin merupakan suatu perbuatan yang terlalu sering dilakukan yang bertentangan dengan suara batin, di dalam kehidupan yang sadar, pertentangan tersebut akan menyebabkan pecahnya pribadi seseorang, sehingga di dalamnya akan selalu dirasakan konflik-konflik (Wulandari, 2018,: 22).

Kurt Lewin dalam buku Henry Clay Smith yang berjudul Personality Adjusment, menyebutkan bahwa konflik memiliki tiga pola dasar, yaitu: konflik mendekatmendekat (approach-approach conflict), konflik mendekat-menjauh (approachavoidance conflict), dan konflik menjauh-menjauh (avoidance-avoidance conflict) (Shofwati, 2018: 27).

1) Konflik mendekat-mendekat (approach-approach conflict)

Konflik mendekat-mendekat ini timbul ketika dihadapkan dengan dua motif konflik yang keduanya sama-sama positif (menyenangkan atau menguntungkan) sehingga nantinya muncul kebimbangan untuk memilih satu diantaranya.

2) Konflik mendekat-menjauh (approach-avoidance conflict)

Konflik mendekat-menjauh ini timbul ketika dalam waktu yang bersamaan dihadapkan dengan dua motif yang berlawanan mengenai satu objek. Motif 
pertama yaitu positif (menyenangkan), dan motif kedua yaitu negatif (merugikan, atau tidak menyenangkan). Karena itu akan muncul kebimbangan, apakah akan mendekati atau menjauhi objek tersebut.

3) Konflik menjauh-menjauh (avoidance-avoidance conflict)

Konflik menjauh-menjauh ini timbul ketika pada saat yang bersamaan dihadapkan dengan dua motif yang sama-sama negatif (tidak menyenangkan). Dari konflik ini akan muncul kebimbangan karena harus menjauhi motif yang satu atau harus memenuhi motif yang lain juga negatif.

\section{Metode}

Pendekatan penelitian yang digunakan adalah kualitatif sedangkan metode penelitian yang digunakan adalah metode deskriptif analisis. Menurut Bogdan dan Taylor (Muhammad, 2014: 30), mendefiniskan metodologi kualitatif sebagai prosedur penelitian yang menghasilkan data deskriptif berupa kata-kata tertulis atau lisan dari orang-orang dan perilaku yang dapat diamati. Pendekatan kualitatif dalam penelitian ini digunakan untuk mengumpulkan data yang didapat dalam teks sehingga lebih menekankan kepada data kata-kata tertulis yang terdapat dalam novel Pertanyaan Kepada Kenangan karya Faisal Oddang. Metode deskirptif analisis dalam penelitian ini digunakan untuk mendeskripsikan unsur-unsur intrinsik dari novel, lalu mendeskripsikan konflik batin yang dialami tokoh dalam novel Pertanyaan Kepada Kenangan karya Faisal Oddang.

Sumber data dalam penelitian ini adalah buku novel Pertanyaan Kepada Kenangan karya Faisal Oddang. Novel ini diterbitkan oleh gagas media pada tahun 2016 (cetakan pertama) dengan jumlah halaman 203 halaman. Sedangkan, data penelitian ini adalah data analisis terkait unsur intrinsik novel, dan konflik batin apa saja yang dialalami tokoh Rinai yang terkandung dalam novel Pertanyaan Kepada Kenangan karya Faisal Oddang. Teknik pengumpulan data yang digunakan dalam penelitian ini yaitu teknik simak dan teknik catat. Metode simak digunakan untuk membaca kritis novel Pertanyaan Kepada Kenangan karya Faisal Oddang agar mendapatkan data terkait unsur intrinsik novel beserta konflik batin yang terkandung di dalamnya. Teknik catat digunakan untuk menandai kata atau kalimat yang mengandung unsur intrinsik dan konflik batin yang dialami tokoh dalam novel Pertanyaan Kepada Kenangan karya Faisal Oddang. Selanjutnya kata atau kalimat tersebut dimasukan ke dalam kartu data untuk dianalisis. Untuk mempermudah dalam pengumpulan data, maka peneliti menggunakan kartu pengumpulan data. 


\section{Hasil}

Hasil dari penelitian yang dilakukan pada novel Pertanyaan Kepada Kenangan karya Faisal Oddang, peneliti menemukan hasil analisis berupa unsur intrinsik, struktur kepribadian psikologi sastra menurut Sigmund Freud, dan konflik menurut Kurt Lewin. Berikut akan dijelaskan hasil analisis tersebut.

\section{Unsur Intrinsik Novel Pertanyaan Kepada Kenangan Karya Faisal Oddang Tema}

Tema yang terkandung dalam novel Pertanyaan Kepada Kenangan karya Faisal Oddang terbagi menjadi dua yaitu tema mayor dan tema minor. Tema mayor yang terdapat dalam novel Pertanyaan Kepada Kenangan karya Faisal Oddang bertema tentang percintaan yang dialami tokoh utama Rinailah Rindu. Percintaan yang dialami Rinai sangat rumit. Sahabat yang sudah dianggap sebagai kakak menyatakan cinta kepada Rinai, dan seseorang dari masa lalu yang pernah meninggalkannya datang kembali menyatakan cintanya.

Sedangkan tema minor yang terkandung dalam novel Pertanyaan Kepada Kenangan karya Faisal Oddang yaitu persahabatan dan sosial budaya. Tokoh Rinai, Wanua, dan Lamba, pada awalnya mereka adalah sahabat. Namun, semuanya berubah ketika Lamba tiba-tiba membatalkan pernikahannya dengan Rinai. Hal itu yang menjadi benteng antara Wanua dengan Lamba. Tema sosial-budaya yang terjadi pada novel yaitu awalnya Rinai dan Lamba adalah sepasang kekasih namun semuanya berubah ketika Rinai dan Lamba ingin membawa hubungannya ke jenjang yang lebih serius. Cinta Rinai dan Lamba harus berakhir karena sebuah adat. Pernikahan mereka ditolak oleh keluarga Lamba, dikarenakan Lamba belum melaksanakan upacara kematian (rambu solo) untuk Papanya. Tema sosial budaya Toraja terkandung dalam novel Pertanyaan Kepada Kenangan karya Faisal Oddang ini.

\section{Tokoh dan Penokohan}

Tokoh utama dalam novel Pertanyaan Kepada Kenangan karya Faisal Oddang adalah Rinai, dan tokoh tambahan dalam novel yaitu Wanua, Lamba, Tenri, Karra, Mama Lamba, Ibu Rinai, dan Penjual Suvenir.

Alur

Novel Pertanyaan Kepada Kenangan karya Faisal Oddang menggunakan alur campuran, karena cerita yang diceritakannya tidak selalu maju ataupun mundur, namun diselingi dengan alur maju atau alur mundur. Pada awal novel ini menceritakan kehidupan Rinai di Makassar dan Toraja. Novel ini diawali dengan cerita peristiwa Rinai di Makassar dengan alur mundur, kemudian dilanjutkan dengan peristiwa Rinai yang ke Toraja untuk menenangkan diri, sekaligus meliput festival kesenian Toraja International Festival. Saat menceritakan kegiatan Rinai di Toraja untuk meliput, menggunakan alur maju karena diawali dengan tujuan dirinya ke Toraja. Ketika di Toraja, Rinai bertemu dengan mantan pacarnya, bagian ini menggunakan alur mundur. 
Rinai mengingat tentang kejadian tiga tahun lalu ketika pernikahannya dengan Lamba ditolak oleh keluarga Lamba karena adat.

Tidak hanya itu, di Toraja Rinai bertemu dengan sahabatnya Wanua. Hal tersebut membuat tujuan Rinai ke Toraja sepenuhnya berhasil, tetapi sepenuhnya gagal. Rinai berhasil mendapatkan data untuk tulisannya, tetapi gagal untuk menenangkan pikirannya. Rinai kembali ke Makassar dan secara tidak sengaja bertemu dengan Wanua. Pada bagian tersebut pengarang menggambarkan alur maju, dan alur mundur. Tahapan alur yang terdapat dalam novel Pertanyaan Kepada Kenangan karya Faisal Oddang terdiri atas eksposisi, komplikasi, klimaks, relevasi, dan denoument (penyelesaian).

\section{Latar}

Latar cerita dalam novel Pertanyaan Kepada Kenangan karya Faisal Oddang dibedakan menjadi tiga yaitu latar tempat, latar waktu, dan latar sosial budaya. Pertama, latar tempat dalam novel terdiri dari Toraja, Makale, Makassar, Kedai Kopi Tongkonan, Restoran, Kamar, Taksi, Hotel, Mobil, Kete Kesu, Gedung Kesenian Sulawesi Selatan, Pantai Losari, Warung Pinggir Pantai, Rumah Rinai, Kampung Kambira, Kantin Kantor, Rumah Lamba, Fort Rotterdam, Toilet, Pulau Samalona, dan Bukit Sion.

Kedua, latar waktu dalam novel terdiri dari Sore, Agustus, Malam, Pagi, Tiga Tahun Lalu, Siang, dan Dua Tahun Lalu. Ketiga, latar sosial budaya dalam novel menggambarkan adat istiadat kebudayaan Toraja, seperti Upacara rambu solo, makanan khas Makassar dan Toraja, Pakaian adat, tarian daerah, dan pengunaan bahasa daerah atau dialek-dialek Makassar dan Toraja.

\section{Sudut Pandang}

Sudut pandang atau point of view merupakan bagian dari sebuah unsur fiksi yang mempengaruhi penyajian cerita. Sudut pandang adalah cara bercerita pengarang untuk menggambarkan tokoh yang diceritakannya. Sudut padang yang digunakan Faisal Oddang dalam novel Pertanyaan Kepada Kenangan adalah sudut pandang orang pertama " $A k u$ " yang diperankan oleh tokoh Rinai. Sudut pandang orang pertama berperan sebagai tokoh utama yang menceritakan peristiwa-peristiwa yang merupakan pengalamannya.

\section{Amanat}

Amanat merupakan pesan yang ingin disampaikan pengarang lewat cerita kepada pembacanya. Amanat dalam karya sastra dapat secara tersirat (implisit) ataupun tersurat (eksplisit). Amanat tersirat yang terkandung dalam novel Pertanyaan Kepada Kenangan karya Faisal Oddang adalah sebagai manusia kita harus pintar menghadapi masa lalu, ketika dihadapkan dengan masa itu kita tidak boleh terus-terusan terpuruk, kita harus bangkit dan ada mimpi yang harus diwujudkan.

\section{Struktur Kepribadian Tokoh dalam Novel Pertanyaan Kepada Kenangan Karya Faisal Oddang}


Id

Id merupakan aspek biologis dalam kepribadian seseorang, Id menekankan manusia agar dapat memenuhi kebutuhan dasar seperti kebutuhan makan, menolak rasa sakit atau ketidak nyamanan. Berikut ini kutipan yang menandakan $I d$ dalam novel Pertanyaan Kepada Kenangan karya Faisal Oddang.

\section{Data 1:}

Kali itu, aku dihadapkan lagi pada aroma tubuh Wanua yang segar, alami tanpa parfum. Aku sangat menyukainya lebih dari aroma parfumku sendiri. Waktu itu, dia belum membuatku sadar atas perasaannya. Entah kenapa, saat menyadari cinta seseorang, pun ketika menyadari mencintainya juga, momen-momen kecil yang pernah dilewatkan menjadi lebih besar dari sebelumnya. Misalnya saja, momen-momen kecil ketika Wanua bersamaku, kini menjadi sangat besar artinya. Kenangan memang jahat, selalu datang seperti muslihat. (Oddang, 2016: 29)

Kutipan di atas menggambarkan Rinai sering sekali mengingat orang dari wanginya. Rinai sangat menyukai aroma parfum Wanua dibanding parfumnya sendiri. Ketika Rinai menyadari bahwa ia mencintai Wanua, momen-momen kecilnya bersama Wanua selalu teringat. Jadi, Id yang dimiliki Rinai adalah menilai seseorang hanya dari wewangiannya saja.

\section{Ego}

Ego adalah struktur kepribadian yang berada diantara alam sadar dan alam bawah sadar. Struktur kepribadian Ego berkembang dari Id, untuk mengontrol kesadaran dan mengambil keputusan atas perilaku manusia. Berikut ini kutipan yang menandakan Ego dalam novel Pertanyaan Kepada Kenangan karya Faisal Oddang.

\section{Data 2:}

Ada masanya, kamu akan benar-benar merasa tidak memiliki apa-apa. Tidak punya siapa-siapa. Kamu hanya akan berdua dengan dirimu sendiri. Masa itu, kamu akan berada pada titik terlemah dari semua yang pernah kamu rasakan dalam hidupmu. Bisa saja, jika kamu tidak punya hati yang kebas, kamu akan terpuruk dan tentu akan berakhir di masa itu juga.

Namun, tidak buatku. Aku punya mimpi, paling tidak sebelum aku mati, mimpi itu harus terwujud. Dan, jika saat ini aku jatuh, aku harus segera bangkit. Aku menyesap kopiku, kemudian memberi pembatas buat bacaanku. (Oddang, 2016: 90).

Kutian di atas menggambarkan ketika Rinai berada dimasa-masa tidak memiliki apa-apa dan tidak punya siapa-siapa, ia tidak ingin terus-terusan terpuruk. Rinai mempunyai mimpi dan ia harus segera bangkit dari keterpurukan. Ego yang dimiliki Rinai adalah bangkit dari keterpurukan dan terus bermimpi. 


\section{Superego}

Superego adalah struktur kepribadian yang berkembang dari ego saat manusia mengerti nilai baik dan nilai buruk bahkan serta nilai moral. Dalam superego tokoh menentukan perilaku dan tindakan yang dilakukan baik dan pantas atau sebaliknya. Berikut ini kutipan yang menandakan Superego dalam novel Pertanyaan Kepada Kenangan karya Faisal Oddang.

\section{Data 3:}

Aku membiarkan Lamba menemaniku—ke mana pun aku ingin pergi, ia akan mengantarku. Kupikir itu salah satu caranya untuk menebus, dan bagiku itu adalah sebuah kesalahan. Salah karena aku memberinya kesempatan untuk lebih dekat denganku. Namun, aku takut lebih bersalah dengan menjauhinya, aku takut menyesal. Aku tidak ingin memperkeruh hubunganku dengan dia dan mamanya. Bisa saja ketakutanku itu juga termasuk kesalahan. (Oddang, 2016: 36)

Pada kutipan tersebut menggambarkan tokoh Rinai untuk membiarkan Lamba menemaninya dan mengantarnya kemanapun. Rinai merasa salah telah membiarkan itu, Rinai berpikir bahwa itu merupakan cara Lamba untuk menebus kesalahannya. Jadi, superego yang dimiliki Rinai adalah sadar bahwa yang dia lakukan tidak benar dengan membiarkan Lamba seperti itu. Namun, Rinai tidak ingin menyesal dengan menjauhinya dan ia tidak mau memperkeruh hubungannya dengan mama Lamba.

\section{Konflik Batin Tokoh Utama dalam Novel Pertanyaan Kepada Kenangan Karya Faisal Oddang \\ Konflik Mendekat-Mendekat (approach-approach conflic)}

Konflik mendekat-mendekat ini timbul ketika dihadapkan dengan dua motif konflik yang keduanya sama-sama positif (menyenangkan atau menguntungkan) sehingga nantinya muncul kebimbangan untuk memilih satu diantaranya

Konflik mendekat-mendekat pertama dalam novel Pertanyaan Kepada Kenangan karya Faisal Oddang muncul ketika tokoh utama yaitu Rinai saat dirinya diterima kerja di Majalah Lancong. Rinai terpilih dan ditempatkan di sektor Indonesia Timur. Rinai merasa senang di tempat di Makassar karena ia mempunyai sahabat kecil di kota tersebut. Hal tersebut dapat ditunjukkan Oddang dengan kutipan sebagai berikut.

Data 4:

Setahun setelah menjadi Sarjana Sastra di Universitas Indonesia, aku mendaftar ke sebuah majalah pariwisata internasional, Majalah Lancong. Aku beruntung diterima dan ditempatkan di sektor Indonesia Timur. Aku harus meninggalkan rumah dan pindah ke Makassar. Kenapa Makassar? Aku punya satu alasan, bukan karena Makassar merupakan kota terbesar di sektorku, melainkan karena aku punya sahabat kecil di kota ini. Wanua Maraja. Kami bersahabat sejak SMP dan harus berpisah setahun sebelum kuliah. Orangtuanya dipindah tugaskan kembali ke kota kelahirannya, Makassar. (Oddang, 2016: 25) 
Konflik mendekat-mendekat yang selanjutnya dalam novel Pertanyaan Kepada Kenangan karya Faisal Oddang muncul ketika Wanua menyusul Rinai ke Makale. Disaat itu Rinai dihadapkan oleh dua pilihan yaitu antara Wanua dan Lamba, keduanya samasama Rinai sukai. Wanua yang merupakan sahabatnya yang masih dicintai, dan Lamba yang merupakan mantan pacarnya kembali dan ia membuktikan masih mencintai Rinai. Hal tersebut dapat ditunjukkan Oddang dengan kutipan sebagai berikut.

\section{Data 5:}

Di tengah keriuhan, Wanua merasukkan diri menembus lalu-lalang orang, ia mengejar posisi terdekat dengan tubuhku. Sekarang, di tengah keramaian pinggir kolam Makale, aku berdiri di tengah dua lelaki yang katanya mencintaiku.

Wanua, sahabatku, yang pernah dan masih kucintai, dan malam ini kupikir ia tidak memikirkanku, apalagi menyusulku. Lamba, mantan pacar yang pernah meninggalkanku, sekarang ia kembali, membuktikan ia masih mencintaiku dan menginginkanku kembali. Dua sosok yang kontras wartawan dan pengusaha kopi. Yang satu selengean, satunya lagi sosok klimis. Jujur, keraguanku memuncak pada detik-detik terakhir pergantian tahun. (Oddang, 2016: 179)

Kedua data di atas menggambarkan bahwa tokoh utama Rinai mengalami konflik batin berupa konflik mendekat-mendekat. Hal itu terlihat dari beberapa situasi yang mengekspesikaan kebahagiaan dan kesenangan bagi tokoh utama. Ketika Rinai diterima di Majalah Lancong dan ditempatkan di Makassar, Rinai memiliki sahabat di kota tersebut. Selain itu kebahagiaan terlihat dari Rinai ketika dihadapkan dengan pilihan antara Wanua dan Lamba. Berdasarkan hal tersebut, manusia selalu dihadapkan pada dua atau beberapa pilihan hidup. Rinai dihadapkan pada dua pilihan yang kesemuanya samasama menguntungkan bagi dirinya sehingga mengakibatkan konflik batin.

Konflik Mendekat-Menjauh (approach-avoidance conflict)

Konflik mendekat-menjauh ini timbul ketika dalam waktu yang bersamaan dihadapkan dengan dua motif yang berlawanan mengenai satu objek. Motif pertama yaitu positif (menyenangkan), dan motif kedua yaitu negatif (merugikan, atau tidak menyenangkan). Karena itu akan muncul kebimbangan, apakah akan mendekati atau menjauhi objek tersebut.

Konflik mendekat-menjauh yang pertama adalah ketika Lamba mengajak Rinai bertemu dengan alasan mamanya. Rinai sebenernya tidak senang bertemu dengan Lamba, namun Rinai tidak ingin mengecewakan mama Lamba. Hal tersebut dapat ditunjukkan Oddang dengan kutipan sebagai berikut.

\section{Data 6:}

"Mama mau ketemu katanya, bisa?"

Mamanya lagi, mamanya lagi. Lamba tahu betul di mana letak titik lemahku. Aku tidak pernah ingin mengecewakan seorang ibu. Aku sudah cukup menyesal ketika aku gagal menikah, aku sudah menyesal membiarkan Ibu dikalahkan rasa kecewanya. Penyakit jantungnya kumat-dan ia tidak bisa bertahan hidup. Kehilangan mengajariku banyak hal, salah satunya, aku tidak ingin membuat orang lain kehilangan sekalipun yang hilang itu hanya harapan.

"Nay, bisa, kan? Kami lagi di jalan, kata Mama kalau kamu selesai nanti bisa aku jemput di sana, dekat kok." 
Aku tidak punya alasan. Aku mengingat betul, mama Lamba menguatkanku, ia masih terus menumbuhkan sisa-sisa harapanku waktu itu. Ia menguatkanku ketika keluarga besarnya menolak pernikahanku dengan anaknya. Aku ingin membalas dengan tidak mengecewakannya. (Oddang, 2016: 76)

Konflik mendekat-menjauh yang kedua adalah ketika Wanua menyatakan perasaanya kembali kepada Rinai, dan Wanua telah membatalkan pernikahannya dengan Karra. Kejadian itu membuat Rinai senang, namun Rinai sudah berjanji untuk menemani Lamba ke Toraja untuk menemaninya mengadakan upacara rambu solo sekaligus meliput untuk tulisannya. Hal tersebut dapat ditunjukkan Oddang dengan kutipan sebagai berikut.

Data 7:

Sekalipun wanua memunculkan fakta baru, yang jujur membuatku terkejut, keputusanku untuk ke Toraja sama sekali tidak akan kubatalkan. Bukan karena aku sudah mencintai Lamba dan aku sudah tidak mencintai Wanua. Bukan. Pertama, aku sudah berjanji kepada Lamba, dan kepada mamanya. Mengingkari janji adalah membohongi diri sendiri, itu kejahatan yang tidak bisa ku maafkan. Selanjutnya, kantorku menugasi untuk meliput rambu solo. "Ini sangat penting, Rinai," begitu kata koordinator liputanku, yang segera kuiyakan. Aku tahu meskipun bukan suatu persyaratan, jika menolak tugas ini, aku tentu bisa mengurangi nilai buat Travel Writer of the Year. Maksudku, nilai loyalitasku terhadap pekerjaan akan jatuh. Aku telah utuh, tekadku bulat untuk pergi. (Oddang, 2016: 148-149)

Kedua data di atas menggambarkan bahwa tokoh utama mengalami konflik batin berupa konflik mendekat-menjauh. Hal itu terlihat dari beberapa situasi yang mengekspesikaan kesenangan dan ketidak senangan bagi tokoh utama. Ketidak senangan terlihat ketika Lamba mengajak Rinai untuk bertemu, namun Lamba selalu menggunakan alasan Mamanya. Rinai senang untuk bertemu Mama Lamba karena ia tidak ingin mengecewakan seorang Ibu sekalipun itu Mama Lamba. Selanjutnya, saat Wanua memunculkan fakta baru bahwa ia masih mencintai Rinai, namun Rinai sudah berjanji untuk datang ke Toraja dan Rinai senang bisa ikut mengadakan upacara rambu solo sekaligus meliput untuk tugas dari kantor terkait rambu solo. Rinai dihadapkan pada dua pilihan yang disenangi dan tidak disenangi bagi dirinya sehingga mengakibatkan konflik batin.

4) Konflik Menjauh-Menjauh (avoidance-avoidance conflict)

Konflik menjauh-menjauh ini timbul ketika pada saat yang bersamaan dihadapkan dengan dua motif yang sama-sama negatif (tidak menyenangkan). Dari konflik ini akan muncul kebimbangan karena harus menjauhi motif yang satu atau harus memenuhi motif lain yang sama-sama negatif.

Konflik menjauh-menjauh yang pertama ketika Rinai ke Toraja untuk menenangkan diri dari Wanua, namun di Toraja ia bertemu dengan Lamba yang merupakan mantan pacarnya itu. Hal tersebut dapat ditunjukkan Oddang dengan kutipan sebagai berikut.

Data 8:

Aku benar-benar kacau malam itu. Belum reda keresahanku atas permintaan Nua menjadi pacarku, aku kembali dihadapkan pada kenyataan yang belum siap kuterima; Lam kembali tanpa banyak berubah. (Oddang, 2016: 17) 
Konflik menjauh menjauh yang kedua adalah ketika Rinnai dimintai tolong oleh Karra untuk membantu memilihkan kutipan yang bagus buat undangan pernikahan Karra dengan Wanua. Kedua hal tersebut sangat tidak disenangi Rinai, Karra telah melukainya dihari-hari terakhir pernikahannya dengan Wanua. Hal tersebut dapat ditunjukkan Oddang dengan kutipan sebagai berikut.

Data 9:

"Rinai, Tolong bantu pilih kutipan yang cocok buat undangan pernikahan aku. Aku sedikit bingung, kamu barangkali bisa bantu."

Begitu pengantar Karra di badan e-mail, kemudian aku mengunduh lampirannya. Hatiku terkoyok sebagai seorang yang punya cinta. Apa maksud Karra melakukan ini semua? Tidak Sadarkah dia telah banyak sekali menyakitiku di hari-hari terakhirnya ini? (Oddang, 2016:127)

\section{Data 10:}

Kuputuskan untuk tidak membalas surel dari Karra. Bahkan, sebisa mungkin aku tidak ingin lagi berhubungan dengan Wanua sebelum akhirnya dia menjadi sah milik Karra. Aku tidak ingin mengharapkan yang pada akhirnya tidak akan kumiliki, jika kelak ku miliki yang tidak pernah kuharapkan, barangkali itulah cara cinta menguji. Bagaimanapun juga aku akan menempuhnya.

Aku telah melepas lepas-lepas nya. (Oddang, 2016: 129)

Data-data di atas menggambarkan bahwa tokoh utama mengalami konflik batin berupa konflik menjauh-menjauh. Hal itu terlihat dari beberapa situasi yang mengekspesikaan ketidak senangan bagi tokoh utama. Ketidak senangan terlihat ketika Rinai di Toraja bertemu dengan Lamba, lelaki dari masa lalunya itu. Padahal niat Rinai ke Toraja untuk menenangkan diri dari Wanua. Selanjutnya, ketika Wanua tiba-tiba akan menikah dengan Karra, dan Karra meminta bantuan Rinai untuk memilihkan kutipan yang akan ditempel pada undangan pernikahannya. Rinai dihadapkan pada dua pilihan yang tidak disenangi bagi dirinya sehingga mengakibatkan konflik batin.

\section{Simpulan}

Berdasarkan hasil penelitian terhadap konflik batin tokoh utama dalam novel Pertanyaan Kepada Kenangan karya Faisal Oddang. Peneliti menganalisis unsur intrinsik sebagai unsur pembangun dalam novel Pertanyaan Kepada Kenangan karya Faisal Oddang. Hasil penelitian psikologi sastra terhadap tokoh utama, terdapat Id, Ego, dan Superego yang dialami Rinai. Konflik batin tokoh utama yang dialami Rinai berdasarkan konflik mendekat-mendekat, konflik mendekat-menjauh, dan konflik menjauh-menjauh. Konflik tersebut muncul ketika Rinai dihadapkan pada sebuah pilihan antara disenangi, dan tidak disenangi bagi dirinya sehingga mengakibatkan konflik batin.

Hasil penelitian ini menggambarkan tokoh utama Rinai mengalami konflik batin, dilihat dari beberapa situasi yang mengekspesikan tokoh. Pertama, ketika Rinai diterima di majalah pariwisata internasional dan di tempatkan di Makassar, selain itu Rinai dicintai oleh dua pria sekaligus. Kedua, ketika Lamba mengajak Rinai untuk bertemu dengan alasan mamanya. Ketiga, ketika Rinai bertemu Lamba di Toraja, padahal niat 
Rinai ke Toraja untuk menenangkan diri dari perasaan gamang setelah Wanua menyatakan cintanya. Dari hasil penelitian bahwasannya konflik batin yang di alami tokoh Rinai cukup berat, Rinai dihadapkan pada beberapa pilihan yang harus dipilih dalam waktu bersamaan sehingga mengakibatkan konflik batin.

\section{Ucapan Terima Kasih}

\section{Daftar Pustaka}

Darmawati, U. (2018). Prosa Fiksi: Pengetahuan dan Apresiasi. Klaten: PT.Intan Pariwara.

Minderop, A. (2011). Psikologi Sastra: Karya Sastra, Metode, Teori, dan Contoh Kasus. Jakarta: Yayasan Pustaka Obor Indonesia.

Muhammad. (2014). Metode Penelitian Bahasa. Jogjakarta: Ar-Ruzz Media.

Nurgiyantoro, B. (2015). Teori Pengkajian Fiksi. Yogyakarta: Gadjah Mada University Press.

Oddang, F. (2016). Pertanyaan Kepada Kenangan. Jakarta: Gagas Media.

Ratna, N. K. (2015). Teori, Metode, dan Teknik penelitian Sastra: dari Strukturalisme hingga Postrukturalisme Persektif Wacana Naratif. Yogyakarta: Pustaka Pelajar.

Sehandi, Y. (2018). Mengenal 25 Teori Sastra. Penerbit Ombak.

Shofwati, U. (2018). Konflik Batin Dua Tokoh Utama Novel Utsukushisa To Kanashimi To Karya Yasunari Kawabata (Sebuah Kajian Psikologi Sastra). Skripsi. Universitas Diponegoro, Semarang. http://eprints.undip.ac.id/61657/

Suherman, T. L. (2017). Analisis Psikologis Tokoh Andre dalam Novel Ibuku Perempuan Berwajah Surga; Kajian Teori Kepribadian Sigmund Freud. Skripsi. Universitas Mataram, Nusa Tenggara Barat. http://eprints.unram.ac.id/3005/

Wellek, Rene \& Warren, A. (2016). Teori Kesusastraan. Jakarta: PT. Gramedia Pustaka Utama.

Wiyatmi. (2009). Pengantar Kajian Sastra. Yogyakarta: Pustaka Book Publisher.

Wulandari, W. F. (2018). Analisis Konflik Batin Tokoh Utama Tegar dalam Novel Sunset dan Rosie karya Tere Liye (Pendekatan Psikologi Sastra). Skripsi. Universitas Sanata Dharma, Yogyakarta. https://repository.usd.ac.id/31728/2/101224055_full.pdf 